\title{
The effects of publishing processes on scientific thought. Typography and typology in prehistoric archaeology (1950s-1990s)
}

\author{
Sébastien Plutniak \\ Centre Émile Durkheim, Université de Bordeaux, Bordeaux, France \\ Traces laboratory, Toulouse, France
}

[Author version of: Sébastien Plutniak [2020], "The Effects of Publishing Processes on Scientific Thought. Typography and Typology in Prehistoric Archaeology (1950s-1990s)," Science in Context, 33, 3, pp. 273-297, DOI: 10.1017/S0269 889721000053.]

\section{Contents}

1 Introduction. Typology and typography as efforts of rationalisation

2 Laplace's typologie analytique and its notation system: standardised expressions for describing lithic objects

3 Publishing in prehistoric archaeology from the 1950 s to the 1970 s 3.1 Offprints as an editorial format and historical source . . . . . . .

3.2 Practising archaeology in a multilingual setting . . . . . . .

4 Typographical obstacles to a methodological innovation

4.1 Typographical arguments in the criticisms of archaeologists . . .

4.2 Printing and typographical constraints ..........

5 Editorial autonomy as a solution

5.1 Dialektikê: the voice of the Groupe international de recherches ty-

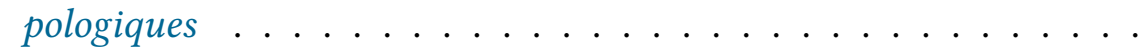

5.2 The Archivio di tipologia analitica: a controversial paper database

5.3 Computer-based treatments of lithic analytical formulas . . . . .

6 Conclusion: towards Big Data. The persistent question of the materiality of representation systems

\begin{abstract}
In the last decades, many changes have occurred in scientific publishing, including online publication, data repositories, file formats and standards.
\end{abstract}


The role played by computers in this process rekindled the argument on forms of technical determinism. This paper addresses this old debate by exploring the case of publishing processes in prehistoric archaeology during the second part of the $2 \mathrm{o}^{\text {th }}$ century, prior to the wide-scale adoption of computers. It investigates the case of a collective and international attempt to standardise the typological analysis of prehistoric lithic objects, coined typologie analytique by Georges Laplace and developed by a group of French, Italian, and Spanish researchers. The aim of this paper is to: 1) present a general bibliometric scenario of prehistoric archaeology publishing in continental Europe; 2) report on the little-known typologie analytique method in archaeology, using publications, archives, and interviews; 3) show how the publication of scientific production was shaped by social (editorial policies, support networks) and material (typography features and publication formats) constraints; and 4) highlight how actors founded resources to control and counterbalance these effects, namely by changing and improving publishing formats.

Keywords: prehistoric archaeology, scientific publishing, print history, standardisation, typography, typology

\section{Introduction. Typology and typography as efforts of ra- tionalisation}

To what extent can the material aspects of publishing processes affect the content of scientific and intellectual productions? Jack Goody's pioneer works on the materiality of writing and cognition (Goody 1977), have made a significant contribution to popularise the idea that causal relationship is a plausible hypothesis. Observing and identifying such relationships is much more difficult in practice, and they are sometimes overemphasised in programmatic statements. In his 1985 lecture on Bibliography and the Sociology of Texts, Donald McKenzie gave an example with his analysis of a quotation from a famous text on literature theory. Addressing the debates on the reachability of one author's intention, he examined the use of capitalisation, quotation marks, and the accuracy of the copied words, aiming to show "that in some cases significantly informative readings may be recovered from typographic signs as well as verbal ones, that these are relevant to editorial decisions about the manner in which one might reproduce a text" (McKenzie 2004, pp. 18-22). Although this example is useful, it was the only case he gave involving typography. Studies combining the history of print and the history of (early) sciences have greatly contributed to increasing the attention paid to the material production of knowledge. In his 1998 masterpiece The Nature of the Book, Johns Adrian noted that in contemporary science studies ${ }^{1}$, "the universal character of science can be appraised as an achievement, warranted and maintained by situated labors", but regrets that, to the contrary, "appreciation of print has too frequently stopped short at the doors of the printing house" (Adrian 1998, pp. 41-42). Looking at the printing process and the multiple printed formats as

\footnotetext{
${ }^{1}$ In this vast literature, notably studies which paying particular attention to the materiality of scientific practices and writings include Shapin and Schaffer 1985, Lenoir 1998, and Gardey 2008.
} 
instruments was key in overcoming this limitation ${ }^{2}$. Moving forward to $20^{\text {th }}$ century science, such a perspective can be applied to the new printing formats that appeared at that time, in particular those related to computers. Looking at the effects of information technology on social ordering in scientific practices, Christine Hine studied changes in contemporary biology due to the use of computers. Investigating databases as instruments and means of communication, she stressed the difficulty in finding "evenly distributed and homogeneous effects", observing that the database was rather an "additional ordering resource" (Hine 2006, p. 291).

Drawing on this scholarship, this paper aims to re-examine the potential relations between publishing processes and the content of scientific productions, from a detailed case study in prehistoric archaeology in the second half of the $20^{\text {th }}$ century. This was a period when mathematics and computing were being gradually introduced into prehistoric archaeology. Two efforts of rationalisation and standardization will be jointly analysed: typography and typological thinking, respectively. Typography is the rationalisation and standardisation of graphic representations of linguistic statements ${ }^{3}$. It specifically includes the definition of the concepts and instruments required to produce graphic documents. Typology is one systematic method of scientific analysis, and is used in different investigative domains $^{4}$ : in philosophy ${ }^{5}$, in mathematics and logic with type theory, in sociology with Max Weber's ideal type ${ }^{6}$, and in archaeology, to study the various objects made by ancestral humans, such as lithic typologies for prehistoric stone tools. In this last field of investigation, typologies are of crucial importance because archaeologists aim to study human past realities without the possibility of relying on the discourses of past actors, thus making naming and categorising central issues.

Typography and scientific investigations are characterised by their practitioners' attempts to rationalise and standardise descriptions. As Adrian stated: "print, like scientific truth, attains the level of universality by the hard, continuous work of real people in real places" (Adrian 1998, p. 42). Whatever the phenomenon studied, efforts to establish classifications, taxonomies or nomenclatures are also based on such rationalisation and standardisation. In addition, typography and typology are related in various ways. First, typological thinking has been applied to typographical characters ${ }^{7}$. Second, and more generally, since the mechanisation of publishing, establishing a typology is to establish relationships between 1) concepts; 2) linguistic representations; and 3) graphic representations. For example, lithic typologies can: 1) distinguish between the concepts of blade and bladelet; 2)

${ }^{2}$ Adrian 1998, pp. 29-30; about Modern science, see also Lowood and Rider 1994.

${ }^{3}$ On the scientific shaping of printed pages see Riders' historical overview (Rider 1998); on the relationships between font design and mathematics, see Adrian's analysis of Joseph Moxon's Mechanick Exercises on the Whole Art of Printing (Adrian 1998, pp. 87-90), and Knuth 1979.

${ }^{4}$ For an analysis of systematicity in science, and an examination of the forms of classification, see Hoyningen-Huene 2013, pp. 42-43. I draw on his definitions: a classification is based on discriminating individual elements into different classes according to an identity criterion; a taxonomy is a hierarchy of classes; a nomenclature is a system for denoting the elements of such a hierarchy.

${ }^{5}$ Carl Hempel identified three meanings for the type concept: classificatory, extreme, and ideal types (Hempel 1965, pp. 156-166).

${ }^{6}$ For an analysis of this ideal type concept, see Coenen-Huther 2003.

${ }^{7}$ Francis Thibaudeau's typology, published in 1921, prefigured a long series of proposals published in the early 1950s: among other examples, one may cite those by Maximilien Vox (1953), Jan Tschichold (1952), Aldo Novarese (1857, then in 1964) and Jean Alesandrini (1979). 
use the syntagms "blade", "pièce laminaire" or "Klinge" (linguistic variation); and 3) print the character strings "blade", "blade" (typographic variation) or " $\lambda \varepsilon \tau i \delta \alpha$ " (linguistic and typographic variations).

Attempts to standardise associations between conceptual, linguistic, and typographical distinctions are aimed at minimising ambiguities. However, discrepancies between these three levels of rationalisation are unavoidable, and this paper aims to empirically study these differences. It addresses the use and dissemination of a standard practice, as well as unexpected variations in this practice that have bypassed the effort of standardisation. Rather than a scenario where the use of publishing formats and standards are rejected for their negative effects (excessive normalisation or uncontrolled variation), I show that researchers can occasionally find resources to control and counterbalance the undesired effects of standardisation. Identifying these effects does not refute the never-ending improvements that are made in attempts to control them.

To this end, this paper studies how archaeologists involved in the development of the "typologie analytique" method attempted to standardise typological methods for describing prehistoric lithic objects. This method was developed by the French archaeologist Georges Laplace ${ }^{8}(1918-2004)$ and then improved with his collaborators. It was one of the major proposals published during the second half of the $20^{\text {th }}$ century in the field of "lithic typology" ${ }^{9}$. Until the 1980 s, the definition of such typologies was one of the main debated issues in prehistoric archaeological research in France. In this context, Laplace faced other researchers such as François Bordes (1919-1981), Denise de Sonneville-Bordes (1919-2008), and Jacques Tixier $\left(1925^{-2018}\right)^{10}$. The proposals varied in how the different typologies were defined, how convenient the typologies were in practice and how proponents could teach them, how effective results could be generated and whether an editorial space could be accessed to publish the results. I analyse the relations between these dimensions to show how, in addition to intellectual arguments, publishing constraints, from the level of editorial policies such as the selection of publication language or the defence of specific trends, to the typographical and technical level, can have transforming effects on scientific productions and practices.

The first section of this paper presents the typologie analytique method; the second section is a general examination of the editorial landscape in prehistoric archaeology in France from the 1950s to 1970s; based on the former data, the third section examines the difficulties encountered by the proponents of the typologie analytique method; and the last section addresses the publishing strategy they adopted to overcome these issues. This study is based on published materials, archives, interviews, and bibliometric data I generated.

${ }^{8}$ About Laplace's scientific career and research, see Plutniak 2017b and Plutniak 2017c. Note that from 1949 Laplace signed his publications as Laplace-Jauretche (adding his first wife's surname); then, from 1958 onward, he signed as Laplace.

${ }^{9}$ However, few works published in English mention this method, e.g. Odell 2004, p. 104.

${ }^{10}$ Important studies include: de Sonneville-Bordes and Perrot 1954, Bordes 1961, Laplace 1966b, Tixier 1963, Brézillon 1983. 


\section{Laplace's typologie analytique and its notation system: standardised expressions for describing lithic objects}

The contents of the "typologie analytique" method have changed over time, from its first definition in the early 1960s to the last publications of its author in the 200os. In general and in its most elaborated state, this method for the study of prehistoric lithic objects included a nomenclature, a notation system to encode the description of lithic objects, a set of typometrical methods (intended to characterise and classify lithic objects based on their metric dimensions), and a set of statistical procedures for collections of lithic objects (those from a same stratigraphical layer, for example).

Throughout his publications, Laplace developed a practical method to encode the result of an analysis of a lithic object using his own nomenclature and notation system. To introduce his method, let us first consider that a lithic piece can be represented by a sentence in natural language (using a relatively systematised technical lexicon) and by a drawing (Figure 1). Laplace added to these modes

Pièce lamellaire, pointe à dos profond total, dextre, rectiligne, façonnée par une retouche biface. Elle porte des retouches complémentaires : plate profonde inverse de la base, surimposée au dos; abrupte marginale directe de la partie distale du bord réservé ; simple marginale directe, tendant vers plate, de la partie proximale du bord réservé.

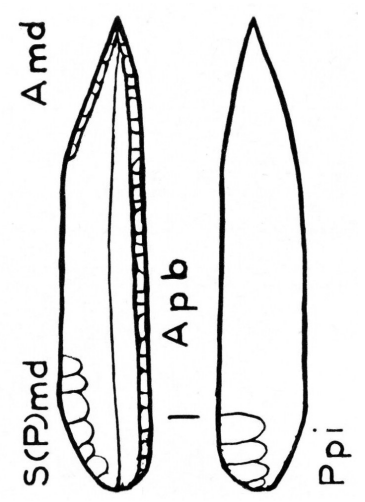

Figure 1: Example of textual and graphic representations of a lithic piece (Laplace 1968, p. 58). The text, in French, uses the technical lexicon of the typologie analytique method.

of representation a third mode: using his method, the lithic piece described in the previous example can also be represented by the following character string (formula 1).

$$
\overline{p D 4} \text { dext rect }[A p b] /=\text { Ppi base. Amd dist }--S(P) \text { md prox }
$$

The apparent complexity of this notation is the result of its gradual improvement. Let us briefly review how this notation system was developed. The two first versions of the lexicon (published in 1954 and 1956) were organised as a finite list of types, each being associated with a number. In 1957, Laplace defined a set of "symbols" formed by one or two letters, to note the typological groups ("groupes typologiques"). The primary types ("types primaires") belonging to a typological group were noted by complementing this group symbol with a number ${ }^{11}$ : for example, $\mathrm{G}_{1}$ for the "grattoir long" primary type (long scraper), or B 7 for the hooked

\footnotetext{
${ }^{11}$ Laplace-Jauretche 1957, p. 138.
} 
burin ("burin busqué"). From 1964, Laplace further systematised this notation (Laplace 1964, pp. 70-71). He distinguished:

- elementary symbols ("symboles élémentaires"), based on the previous rules for the notation of the primary types;

- five basic graphic symbols ("symboles graphiques fondamentaux"), to specify the properties of a primary type or the association between adjacent primary types on the same object;

- four supplementary graphic symbols ("symboles graphiques complémentaires"), referring to the technical properties of an object, or expressing the combination of primary types on the same object;

- three sets of supplementary abbreviations ("abréviations complémentaires"), to describe the retouches ${ }^{12}$.

Note that a difference is made between the "symbols" (alpha-numerical or typographical) and the "abbreviations" of natural language words by apocope: for instance, $\operatorname{dext}($ re), $\operatorname{dist}($ al), prox(imal) (see formula 1).

Laplace gave some examples of how this notation could describe lithic objects. From 1968, the character strings generated with this method, which Laplace described as a "concise notation system" ${ }^{13}$, were called "analytical formulas" ("formules analytiques", Laplace 1968, pp. 56-57). The method to construct these formulas was also described. They had to respect a specific syntax, such as:

$$
\text { TPx position forme (T'P'y) [sigle technique] / retouche complémentaire }
$$

with TPx and T'P' $y$ being chosen from the set of primary type symbols, T'P' $y$ being optional and used to complement the first symbol when two primary types can ambiguously describe the object under study. Laplace wrote:

Thus, we obtain an analytical formula, a genuine syntagma formed of significant units, i.e. elements carrying morphotechnical information which is the only type of information relevant in typology. ${ }^{14}$

In the example presented in Figure 1, the described object combines several properties. To express and clarify the relations between these properties, Laplace defined a set of operators (Figure 2).

After 1968, this notation system became the essential characteristic of the $t y$ pologie analytique for two main reasons. First, it operationalised Laplace's scientific project and fulfilled its epistemic norms (methodological rigour, explicitness, universality, systematicity, analyticity). Secondly, this notation was a descriptive

\footnotetext{
${ }^{12}$ In archaeological analysis of stone knapping, retouches refer to "all forms of intentional secondary modification”, including edge-limited and large removals (Odell 2004, p. 65).

${ }^{13}$ In 1966, Laplace used the periphrasis "[u]n système concis de notation" (Laplace 1966a, p. 201).

${ }^{14 " A i n s i, ~ n o u s ~ a b o u t i s s o n s ~ a ̀ ~ u n e ~ f o r m u l e ~ a n a l y t i q u e, ~ v e ́ r i t a b l e ~ s y n t a g m e, ~ f o r m e ́ e ~ d ' u n i t e ́ s ~ s i g n i f i c a-~}$ tives, c'est-à-dire d'éléments porteurs d'information morphotechnique seuls pertinents en typologie." (Laplace 1968, p. 57). All translations of publications, archive documents and interviews quotations are mine.
} 


\begin{tabular}{|c|c|c|}
\hline Signe & Enoncé & Signifié \\
\hline $\begin{array}{c}- \\
-- \\
= \\
+\stackrel{\text { ou } \mathrm{n}}{(} \\
(1)\end{array}$ & $\begin{array}{l}\text { surlinéation } \\
\text { tiret simple } \\
\text { tiret double } \\
\text { tiret dédoublé } \\
\text { point } \\
\text { plus ou intersection } \\
\text { parenthéses } \\
\text { crochets } \\
\text { barre oblique }\end{array}$ & $\begin{array}{l}\text { laminarité } \\
\text { adjacence continue sur le même bord } \\
\text { adjacence discontinue sur la même bord } \\
\text { adjacence surimposée sur le même bord } \\
\text { opposition } \\
\text { composition } \\
\text { tendance } \\
\text { caractéristique technique } \\
\text { complémentarité }\end{array}$ \\
\hline
\end{tabular}

Figure 2: Summary of the "signes analytiques" (Laplace 1968, p. 57), see Table 1 for an English version. Note the typographical mistake in the third line of the third column (la instead of $l e$ ).

Table 1: English version of the summary of the "signes analytiques" (Laplace 1968, p. 57).

\begin{tabular}{cll}
\hline Sign & Utterance & Signified \\
\hline- & overline & blade feature \\
- & simple dash & continue adjacency on the same edge \\
-- & double dash & discontinue adjacency on the same edge \\
$=$ & duplicated dash & overlapping adjacency on the same edge \\
. & point & opposition \\
+ or $\cap$ & plus or union & composition \\
() & parentheses & tendency \\
{[]} & brackets & technical characteristics \\
$/$ & stroke & complementarity \\
\hline
\end{tabular}


standard, complementing existing publishing formats, which enabled archaeologists to exchange data. Before addressing the use and limitations of this format, I will give a general analysis of the publishing field in prehistoric archaeology over the period when the typologie analytique method was evolving.

\section{Publishing in prehistoric archaeology from the 1950 s to the 1970 s}

In this section, Laplace's offprint collection is used as a quantitative historical source to gain a general picture of the research community in prehistoric archaeology and to locate Laplace's social position within it. It also gives a means to address some particular aspects of this field of practice, including its degrees of internationalisation and multilingualism.

\subsection{Offprints as an editorial format and historical source}

To delimit the period of growth of the typologie analytique method, I start from 1949, the year of Laplace's first archaeological publication, and end in 1973, when the second journal dedicated to this method was created, the Archivio di tipologia analitica. This journal was a key in diffusing the typologie analytique beyond its place of origin in France.

There is no general bibliographic database for prehistoric archaeology which generally covers publications between 1949 and 1973. Therefore, I worked with a sample: Laplace's offprint collection. Offprint publications are unique in that they are printed documents, generally sent personally by authors or editors to potential readers. In the second half of the $20^{\text {th }}$ century, this editorial format was still important for authors, because they contributed to their scientific sociability. Consequently, offprints are a relevant proxy to reconstitute the social networks of scientists. This importance is illustrated, for example, in the letters Laplace exchanged with his Basque editors about his contribution to a collective book in honour of the archaeologist Telesforo de Aranzadi (Laplace 1962):

I write this letter to inform you that I ordered not fifty copies of my work but one hundred [...] I would, therefore, be very grateful if you could [...] have fifty new copies printed (in the event, of course, that the typesetting has been kept). You would be doing me a great service because I still need one hundred copies of my articles for shipping and exchange. [...] PS: I will pay you directly for the price of the offprints on my next trip to your country. ${ }^{15}$

\footnotetext{
${ }_{15}$ "Je profite de cette lettre pour vous signaler que j'avais commandé non cinquante exemplaires de mon travail mais cent [...] Je vous serais en conséquence très reconnaissant si vous pouviez [...] faire imprimer cinquante nouveaux exemplaires (dans le cas bien entendu où la composition ait été conservée). Vous me rendriez, ce faisant, un très grand service, car j'ai toujours besoin de cent exemplaires de mes articles pour envoi et échange. [...] PS : je vous réglerai directement le prix des tirages à part à l'occasion de mon prochain voyage dans votre pays." Letter from Georges Laplace to José Juan de Iraola, 01-03-1963, uncatalogued, "correspondencia 1963" folder, files of the Sociedad de Ciencias Aranzadi, San Sebastián-Donostia.
} 
Laplace's insistence, as well as the number of offprints requested, clearly indicate the importance of this editorial format. It is noteworthy that the author was paying for the supplementary copies. In using offprints as a historical source, they can be interpreted as a consequence of the social relationship between the author and the owner of the offprint, who are likely to have known each other. In this context, I aim to build a general picture of publishing in prehistoric archaeology. It can be argued that this method introduces a potential bias because interpersonal relationships determine the distribution of offprints. However, the large size of Laplace's offprint collection warrants the representativeness of this sample.

The dataset was generated by merging two sources: Laplace's files stored at the Musée National de Préhistoire in Les Eyzies-de-Tayac (France) and Laplace's offprint collection at the Traces Laboratory of Archaeology in Toulouse (France). An inventory of the offprints from the Musée National de Préhistoire was found in the digital collection of the museum ${ }^{16}$, and the TrACES offprint collection was digitally catalogued in a tabular format ${ }^{17}$. Information on 2962 offprints was obtained ${ }^{18}$; the sample corresponding to the $1949^{-1973}$ period includes 2014 items, related to 676 different authors.

\subsection{Practising archaeology in a multilingual setting}

In this study, I identified the most frequent journals (in which the offprints were published) and the frequencies of different languages used in the articles.

Table 2 details the twenty most represented journals. It includes the most important French journals (Bulletin de la Société Préhistorique Française ${ }^{19}$, L'Anthropologie, Gallia Préhistoire), and also journals related to Laplace's own intellectual interests and his personal network of collaborations. In this context, there is a high frequency of journals published in foreign countries where he conducted his research, such as Italy ${ }^{20}$ (Rivista di scienze preistoriche, Quaternaria), the French colonies in North Africa (Libyca), and Central Europe (Acta Archaeologica) from Hungary and Acta Musei Moraviae from Czechoslovakia). Similarly, two journals published in Brittany show the relations Laplace had with some prehistoric archaeologists from this region such as Pierre-Roland Giot (1919-2002) (Annales de Bretagne and Bulletin de la Société Archéologique du Finistère).

The countries in which these journals were published do not necessarily reflect the languages used in their articles nor the nationalities of their authors. Although some French journals, such as the Bulletin de la Société Préhistorique Française only published articles in French, others, such as the Italian Rivista di Scienze Preistoriche, published articles in Italian, French, English and German ${ }^{21}$. Consequently, the distribution of the publication languages must be examined more closely.

\footnotetext{
${ }^{16}$ Authored by Christine Cabon when Laplace gave material to the Musée National de Préhistoire. This inventory was stored in a doc text file: automatic extraction and structuring of this information were necessary to get a tabular format (.csv).

${ }^{17}$ I thank Stéphanie Delaguette for sharing these data with me.

${ }^{18}$ These data are published in open access (Plutniak 2017a).

${ }^{19} \mathrm{An}$ analysis of the content of this journal was published to celebrate its $100^{\text {th }}$ anniversary (Soulier 2007).

${ }^{20}$ On Laplace's activities in Italy see Tarantini 2005, Plutniak and Tarantini 2016.

${ }^{21}$ On the internationality of prehistoric archaeology journals in Italy, see Plutniak 2018a.
} 
Table 2: Laplace's offprint collection: the twenty most represented journals between 1949 and 1973 (916/2014 offprints): title, number of articles, country of publication.

\begin{tabular}{lrl}
\hline Title & N & Country \\
\hline Bulletin de la Société Préhistorique Française & 251 & France \\
Annales de Bretagne & 121 & France \\
L'Anthropologie & 89 & France \\
Gallia Préhistoire & 68 & France \\
Rivista di Scienze Preistoriche & 52 & Italy \\
Comptes Rendus de l'Académie des Sciences & 49 & France \\
Congrès Préhistorique de France & 29 & France \\
Archivo de Prehistoria Levantina & 28 & Spain \\
Quaternaria & 27 & Italy \\
Libyca & 26 & France \\
Atti dell'Istituto Italiano di Preistoria e Protostoria & 21 & Italy \\
Bulletin de la Société Archéologique du Finistère & 19 & France \\
Acta Archaeologica & 18 & Hungary \\
Atti e Memorie della Società Toscana di Scienze Naturali & 18 & Italy \\
Bulletin du Musée d'Anthropologie Préhistorique de Monaco & 18 & Monaco \\
Annali dell'Università di Ferrara & 17 & Italy \\
Quartär & 17 & Germany \\
Acta Musei Moraviae & 16 & Czechoslovakia \\
Bulletino di Paletnologia Italiana & 16 & Italy \\
Munibe & 16 & Spain \\
\hline
\end{tabular}

The language of each text was inferred from its title (Figure 3). Results confirm the effect of Laplace's regional foci on the content of the offprint collection, as shown by the over-representation of work published in Romance languages and the notable presence of papers in Slavic languages. The distribution of languages also indicates two characteristics of multilingualism in prehistoric archaeological publications in the study period.

First, this particular collection reflects more generally a context of practice in which prehistoric archaeology was not bounded by the domination of monolingualism. Although the classic scientific languages (German, English, and French) ${ }^{22}$. are present, other languages are prevalent: those spoken in the countries where fieldwork occurred and where archaeological research organisations have appeared more recently (Italy, Slavic countries).

Second, and also linked to this multilingualism, the methods and vocabularies used to build up lithic typologies diversified internationally from the late 1950s in Continental European archaeology. In parallel, an in-depth and uninterrupted discussion on the concepts of type and typology occurred in English-speaking archaeology from the $1940 \mathrm{~s}^{23}$.

In this context, the idea of a divide between the prehistoric archaeological scholarship produced in French and in English after WWII has been advocated

\footnotetext{
${ }^{22}$ The relation between the development of national prehistoric archaeologies and publishing in local languages has also been addressed in two empirical studies: Lang 2000, Kristiansen 2001.

${ }^{23}$ Some landmarks of these debates: an early work (Krieger 1944), a philosophical discussion (Kantman 1969), a conference (Whallon and Brown 1982), a monograph (Klejn 1982), and a more recent synthetic article Tomášková 2005.
} 


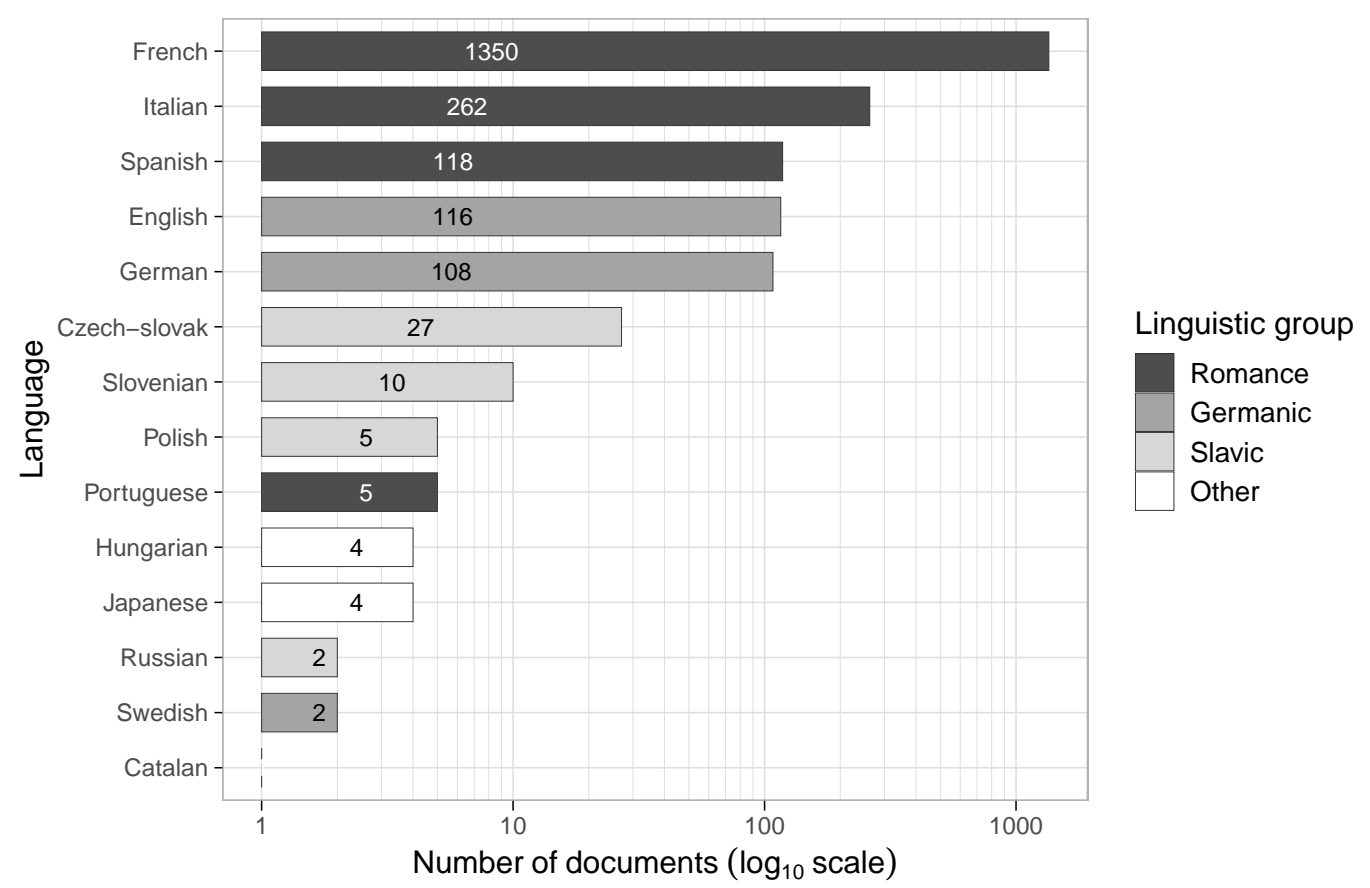

Figure 3: Laplace's offprint collection, number of offprints by language (2014 offprints). Note the logarithmic scale on the x-axis.

and emphasised many times ${ }^{24}$. In the large and general monograph on typology by Adams and Adams Archaeological Typology and Practical Reality, references to debates published in French and other non-English languages are absent, the authors frankly admitting that they "overlooked [them], because of [their] unfamiliarity with the literature in those languages" ${ }^{25}$. In a later book by Odell, Lithic Anal$y$ sis, the European debates are briefly mentioned, but only from the controversy between François Bordes and Lewis Binford, an American archaeologist and one of the major proponents of the "New Archaeology" approach (Odell 2004, pp. 6-7). However, on the contrary, Laplace's offprint collection qualifies the assumption of a strict distinction. First, the idea of a bibliographic divide is not supported because research published in the Germanic languages is prevalent in this offprint collection. Second, nor is the idea of an intellectual divide supported since a quarter of the English papers addressed methodological issues and debates (29/117). Furthermore, there were clear similarities in the methods and epistemic assumptions between Laplace's group and the contemporary proponents of the "New Archaeology" ${ }^{26}$. The typologie analytique method Laplace developed, grounded on rationalist and universalist principles, was seen as a remedy to the national and linguistic diversification of typological systems. Nevertheless, he and his collaborators faced several difficulties in promoting this method.

\footnotetext{
${ }^{24}$ By French scholars, see for example Audouze and Leroi-Gourhan 1981, Olivier and Coudart 1995.

${ }^{25}$ W. Y. Adams and E. W. Adams 1991, p. 266, see also p. 276-277.

${ }^{26}$ On these intellectual relationships see Plutniak 2019, p. 34 .
} 


\section{Typographical obstacles to a methodological innovation}

The diffusion of the typologie analytique method encountered two main obstacles involving typography which are addressed in this section: 1) intellectual obstacles, namely criticisms from other archaeologists active in southwestern Europe, who raised controversial issues almost independently of the similar debates developed in English-speaking prehistoric archaeology; 2) technical difficulties in finding editorial spaces to publish articles based on this typology, due to editorial and typographical reasons.

\subsection{Typographical arguments in the criticisms of archaeologists}

In this section, the typological debates in prehistoric archaeology are addressed from the perspective of how typographical arguments have been used by critics of the typologie analytique.

The American archaeologist Hallam Movius (1907-1987) and the French archaeologist François Bordes were among the main critics of Laplace's method. Bordes was one of Laplace's close friends during the $1950{ }^{27}$ but, then, turned out to be one of the strongest critics against the typologie analytique. He and his wife, Denise de Sonneville-Bordes (1919-2008), regularly published critical notes and reports in the L'Anthropologie journal, edited by their mentor Raymond Vaufrey (1890-1967). In 1963, then in 1965, Bordes published two consecutive notes against Laplace's work. In the second one, entitled "A propos de typologie" ("About typology"), he wrote:

Research, in my opinion, should be directed towards a better knowledge and definition of types and subtypes, rather than towards name changes, or pseudo-mathematical notations. This notation is certainly useful for taking detailed notes but its use makes reading the publications difficult. It is also likely to produce typographical errors. ${ }^{28}$

This typographical argument was reused a few years later by another prehistoric archaeologist also interested in methodological issues in typological research, Michel Brézillon (1924-1993). Before devoting himself to archaeology, he worked as the deputy director of a bookshop in Saint-Mandé (near Paris) in 1945. In the 1960s, he collaborated with an important actor in the field of prehistoric archaeology, André Leroi-Gourhan (1911-1986). In 1968, Brézillon published his $\mathrm{PhD}$. thesis as a book entitled La dénomination des objets de pierre taillée. Matériaux pour un vocabulaire des préhistoriens de langue française (Naming knapped stone objects. Contribution to a vocabulary for French-speaking prehistorians). On Laplace's method, he wrote:

It should not be forgotten that, whatever the value of these descriptive formulas, they cannot constitute a language, since they only represent a means of recording individual variations within groups, whose

\footnotetext{
${ }^{27}$ See Plutniak 2017b, pp. 122-123.

${ }^{28}$ "Les recherches, à mon avis, doivent être orientées vers une meilleure connaissance et une meilleure définition des types et sous-types, plutôt que vers des changements de noms, ou des notations pseudomathématiques. Cette notation est certes utile pour prendre des notes détaillées, mais rend difficile la lecture de toute publication ainsi conçue. Elle se prête aussi beaucoup aux erreurs typographiques." (Bordes 1965, p. 374).
} 
boundaries often remain to be defined and which must, it is a necessity of thought, be represented by verbal expression. ${ }^{29}$

Brézillon's conception of the linguistic features of the "analytical formulas" is radically opposite to Laplace's: he denies all similarities between the notation system of the typologie analytique and languages ${ }^{30}$ and, therefore, denies the relevance of linguistic analytical categories to describe this notation, namely categories such as "syntagma", "word", "phrase", or those used by Laplace for the "analytical signs" ("sign", "utterance", "signified", see Figure 2).

Furthermore, Brézillon believed that an analysis of typologies cannot avoid their discursive dimensions (as a consequence, he wrote, of a "necessary condition of thought"): as a matter of fact, Laplace's analytical formulas cannot be spoken. However, all pasigraphies developed since the $19^{\text {th }}$ century are similar in this respect, and so are programming languages. (Pasigraphies are artificial languages intended to be universal, which only exist as graphical and writing systems, such as Paul Otlet's Universal Decimal Classification or the International maritime signal flags ${ }^{31}$.) Apart from epistemological issues regarding the status of symbols and artificial languages in science, it transpires that proponents of the typologie analytique also encountered difficulties on technical and typographical levels.

\subsection{Printing and typographical constraints}

An analysis of the editorial characteristics of the prehistoric archaeology journals must take into account two characteristics of this field. First, the most important journals were associated with powerful authors who influenced their editorial policies. For instance, the L'Anthropologie journal was co-directed by two rival professors of the Muséum national d'histoire naturelle, Henri-Victor Vallois (1889-1981) for physical anthropology and R. Vaufrey for prehistoric archaeology. In practice, it was almost impossible for a typologie analytique practitioner to publish in this journal due to the disagreements between these archaeologists.

These social and intellectual factors influencing the editorial policies of the journals were complemented by a second, technical, factor: the typographical resources available to the journals' editors. The typologie analytique notation introduced characters not previously used in archaeological publishing ${ }^{32}$. A close examination of this notation cannot, therefore, avoid a pragmatic analysis, in the sense of a linguistic analysis of the realisations of this "language". Here, I draw on previous studies of the material and typographical aspects of scientific publishing as a proxy to highlight social or cognitive aspects.

\footnotetext{
${ }^{29}$ "Il convient de ne pas perdre de vue que, quel que soit l'intérêt de ces formules descriptives, elles ne peuvent constituer un langage et représentent seulement un moyen d'enregistrement des variations individuelles au sein de groupes dont les limites restent souvent à définir et qui doivent, c'est une nécessité de la pensée, être représentés par une expression verbale." (Brézillon 1968, p. 43).

${ }^{30}$ Brézillon's acceptance of the concept of language is restricted to natural languages.

${ }^{31}$ See Auroux 2000, pp. 378-379. Contrary to a pasigraphy, a pasilaly is an artificial language intended to be written and spoken; Esperanto is the most famous example.

${ }^{32}$ Laplace was not the first archaeologist to propose a graphical systematisation for the notation in prehistoric archaeology typologies: Henry Hubert (1879-1941) published a similar method intended for the analysis of Neolithic axes collected in Western Africa (Hubert 1925). However, this method did not use unusual glyphs.
} 
For example, from the case of the $19^{\text {th }}$ century printer Charles Louis Étienne Bachelier, and his printing company Mallet-Bachelier, Norbert Verdier studied the development of mathematical publishing (Verdier 2011). By comparing two prints of the same paper by Evariste Galois, the first from 1829 and the second from 1846, Verdier illustrated how the composition of fractions had improved, which reflected the professionalisation of mathematical publishing.

In a different study, Norbert Verdier and Jenny Boucard addressed the case of the modular congruence in number theory, introduced by Carl Friedrich Gauss in his 1801 Disquisitiones arithmeticae. The authors examined the notation for modular congruence used in the Nouvelles annales de mathématiques journal, a journal created by Olry Terquem which played an important role in the diffusion of Gauss's work to mathematics teachers. Terquem introduced the use of a dotted $\dot{p}$ to note a multiple of the integer $p$, considering that this notation is beneficial for mathematicians and typesetters. Boucard and Verdier also noted that the first use of the $\equiv$ symbol to note modular congruence in this journal occurred in 1849 when the publication moved to another publishing house ${ }^{33}$. The narrow relations between notation systems and mathematical thinking has also been highlighted by Manuel Gustavo Isaac in his study of Gottlob Frege's ideography. He showed how the rules of its formal symbolism reflect and made operational Frege's ambition to combine the syntactic and semantic aspects of his theory of meaning ${ }^{34}$. Notably, Frege rejected the linearity of the writing of natural language and wrote the symbols of his ideography using the two dimensions of the graphical space of the page.

In a similar perspective, studying the editorial and material aspects of scientific publishing demonstrates that introducing formal methods into archaeology, which was an important process in the second half of the $20^{\text {th }}$ century, was not only an abstract and intellectual change. As shown by the case of the typologie analytique notation and by the group of researchers who developed it, this process also implies a practical means of recording and sharing information, determined by technical, intellectual and social constraints.

This can be shown from the examination of two striking examples of symbols which were added to the typologie analytique typeset. Although these symbols were unusual in prehistoric archaeology they were necessary to write the typologie analytique formulas. This indicates that editors would have accepted the use of these symbols and that the printing companies requested to produce the journals would have had the corresponding typographical glyphs ${ }^{35}$. These two symbols were part of the "elementary" and graphic symbols included in the lexicon of the typologie analytique (Figure 2). In 1964, Laplace detailed their purposes:

At the level of primary types, the analysis of simple shapes, either multiple or composite, uses the elementary symbols of the typological list and with basic graphic symbols. The combination of these elementary symbols distinguishes between many secondary types, but

\footnotetext{
${ }^{33}$ Boucard and Verdier 2015, p. 66.

${ }^{34}$ Isaac 2013, pp. 215-225.

${ }^{35}$ Jacques André (1938-) proposed a general distinction between character and glyph: a character is an "abstract information unit used to code text elements"; a glyph is a "geometrical shape used to graphically represent pieces of text” (André 2002, p. 15, my translation from French).
} 


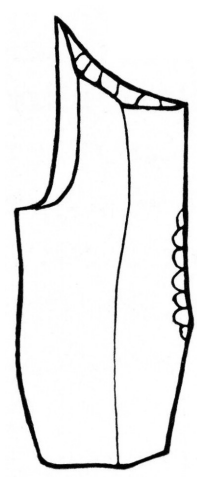

Figure 4: Drawing of a burin sur retouche transversale (from Laplace 1968, p. 58).

greater precision can be achieved by expressing the complexity of a shape by using complementary symbols and abbreviations according to the morpho-technical details empirically observed. ${ }^{36}$

The first example is the notation of the laminar feature ${ }^{37}$ of lithic objects. It shows how the choice of symbols may have been influenced by typographical constraints. In a paper published in 1966 in the Italian journal Rivista di scienze preistoriche $^{38}$, Alberto Broglio (1931-) and Laplace included this feature among those that could be described with their method:

laminar: the overlining of the primary type, signifying the laminar feature of a shape, will not be used in this study [Footnote 1: For strictly typographical reasons.]. The letters $\mathrm{F}$ or $\mathrm{B}$ will be used to state that a lithic piece was reduced from a flake or blade. ${ }^{39}$

The word "surlinéation" used by the authors is clearly a neologism in French. From a typographical perspective, it corresponds to the use of the glyph "-”, called "trait suscrit" in French classical typography vocabulary, and "overline" in the Unicode standard terminology. The use of this symbol in typologie analytique is as follows: a laminar piece described as a burin sur retouche transversale (burin on transversal retouch, Figure 4 ) would be coded $\overline{\mathrm{B} 7}$. In 1966, the Rivista di scienze preistoriche was printed by the Fratelli Parenti di Giuseppe printing company, located in Florence. As the authors noted, the unavailability of the overline typographical glyph

\footnotetext{
${ }^{36}$ "L'analyse des formes simples, multiples et composites, au niveau des types primaires, s'effectue à l'aide des symboles élémentaires de la liste typologique et de symboles graphiques fondamentaux. Si la combinaison de ces symboles élémentaires permet de distinguer déjà de nombreux types secondaires, une plus grande précision peut cependant être atteinte dans l'expression de la complexité d'une forme par l'utilisation de symboles et d'abréviations complémentaires fixés par l'expérience selon les détails morpho-techniques observés et retenus." (Laplace 1964, p. 71).

${ }^{37}$ Namely, the fact a lithic object can be described as a blade. Generally speaking, this property is defined from the ratio between the length and width of the object under examination.

${ }^{38}$ This journal has been published since 1946 by the Istituto Italiano di Preistoria e Protostoria in Florence, and directed by Paolo Graziosi (1906-1988).

${ }^{39}$ "laminaire : la surlinéation du type primaire, significative de toute forme laminaire, ne sera pas utilisée dans ce travail [Note 1 : Pour des raisons strictement typographiques.]. Pour indiquer qu'une pièce est façonnée sur éclat ou sur lame nous aurons recours aux initiales E ou L." (Broglio and Laplace 1966, p. 65).
} 
prompted them to adopt another notation for the laminar character: namely, the prefixion of the primary type symbol by the glyph "L" as, for instance, "LB7".

Two years later, Laplace published a paper in another Italian journal, Origini. Preistoria e Protostoria delle Civiltà Antiche ${ }^{40}$. Overlining glyphs was not a problem for the printing company requested to produce this journal, the Tipografia d'Arte A. L. Picchi, located in Tivoli. However, Laplace was aware that there might be other typographical limitations for a glyph used to represent a relation of composition, namely when a single lithic piece should be described by the association of two primary types or more. So, he advised archaeologists to use one of two glyphs, depending on the typographical resources available: either the glyph used in mathematics to express intersection in set theory ("intersection" glyph, $\cap$ ), or the glyph expressing the sum concept ("plus" glyph, + ). This enabled the

[...] expression, if necessary, of the simple or composite technical characteristic of the essential retouch. The simple technical characteristic is expressed between brackets by a technical symbol, with notation of the relevant position and shape:

TPx position shape (T'P'y) [technical symbol]

A composite technical characteristic is expressed between brackets by a union of technical symbols or primary types, or by their combination, with a notation for the relevant position and shape. This intersection of two sets is noted with the plus sign in the absence of the intersection sign $(\cap)$ :

TPx position shape (T'P'y) [technical symbol or primary type + or $\cap$ technical symbol or primary type]. ${ }^{41}$

Despite this solution anticipated by Laplace, his paper in Origini raised other typographical and printing issues. Figure 5 represents the different glyphs used in this paper to express the composition of two primary types. The printer used two different solutions to make the intersection symbol requested by the author: either an $\mathrm{O}$ or a $\mathrm{Q}$ glyph (using a different font from the Garamond font used for the main text) with its lower part truncated; or an inverted " $u$ ", also using a different font. In both cases, the printer seems to have improvised a solution.

This comparison of papers published in the Rivista and Origini shows the consequences of the availability and inadequacy of the glyphs at the printers on scientific productions. In addition, there is another cause of typographical variation: mistakes made by the person who composed the text for printing (see Figure 2 for an example). For the paper in the Rivista, the printer had the glyphs that the

\footnotetext{
${ }^{40}$ The Origini journal was created in 1967 and directed by Salvatore Puglisi (1912-1985) at the Università degli Studi di Roma "La Sapienza" (dipartimento di scienze dell'Antichità).

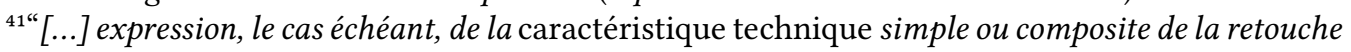
essentielle. La caractéristique technique simple est explicitée entre crochets par le sigle technique avec notation pertinente de position et de forme: TPx position forme (T'P'y) [sigle technique]. La caractéristique technique composite est explicitée entre crochets par la réunion de sigles techniques ou de types primaires, ou par leur combinaison, avec notation pertinentes de position et de forme. Cette intersection de deux ensembles est marquée par le signe plus à défaut du signe intersection $(\cap):$ TPx position forme (T'P'y) [sigle technique ou type primaire + ou $\cap$ sigle technique ou type primaire]." (Laplace 1968, p. 56).
} 


\section{+ ou $\cap$ ou $n$}

Figure 5: The three glyphs used by the printer to note the relationship between several primary types which compose an object (from Laplace 1968, pp. 56-57). The horizontal lines indicate the $\mathrm{x}$-height of the Garamond font used in the main text. This font is illustrated by the French word "ou" ("or" in English).

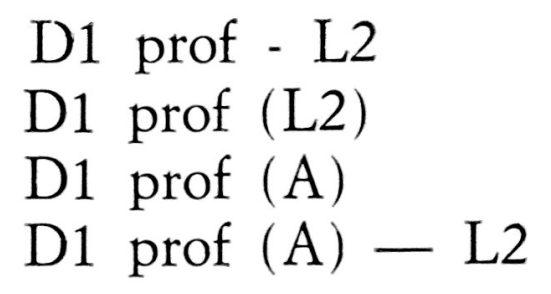

Figure 6: Typographical variation in expressing the relation of adjacency between primary types: hyphens and em dashes (from Broglio and Laplace 1966, p. 90).

authors required ${ }^{42}$ to symbolise the relations of adjacency (em dash, - -), and opposition (interpunct, $\cdot$ ) between two primary types. However, they were occasionally substituted by hyphens (-) and full stops (.), as illustrated in Figures 6 and 7. The article later published in Origini presents a more rigorous use of these glyphs: only full stops and em dashes were used.

The availability of typographical resources and their degree of standardisation thus had direct consequences on the efforts of standardisation made by Laplace and his collaborators in the field of archaeology. The standardisation of digital font formats remains a crucial issue in computer science in the present day ${ }^{43}$. In addition, typographical habits specific to a discipline or an editorial field might also determine the final print of a scientific study. The glyphs presented above were

\footnotetext{
${ }^{42}$ Broglio and Laplace 1966, p. 65.

${ }^{43}$ See the historical summary by Jacques André, which concluded on the Unicode project (André 2002, this article is from a special issue on Unicode).
}

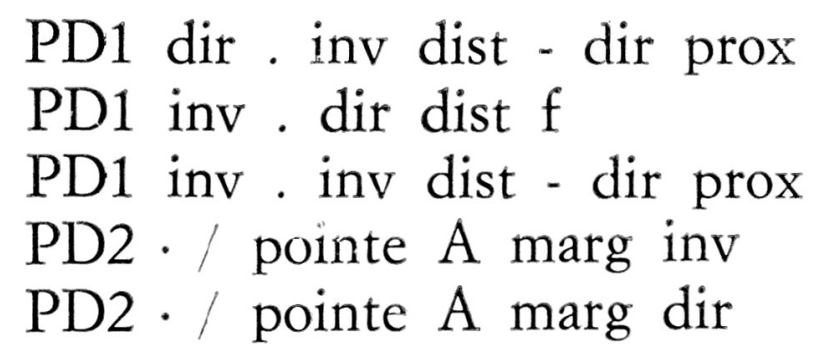

Figure 7: Typographical variation in the use of points to express a relation of opposition between primary types: full stops or interpuncts (from Broglio and Laplace 1966, p. 85). 
problematic for printers specialised in the humanities and used to print archaeological or historical publications; however, the same glyphs would have raised no problems for printers specialised in publishing mathematics or physics research ${ }^{44}$.

To summarise, the method proposed by Laplace encountered two sorts of publishing difficulties: first, criticisms and refusals of other archaeologists; and second, editorial and typographical constraints. To promote their method and to avoid these obstacles, the proponents of the typologie analytique created their own editorial vehicles.

\section{$5 \quad$ Editorial autonomy as a solution}

Creating an editorial media and ensuring control over editorial processes, were means for the proponents of the typologie analytique method to gain autonomy. In this context, two journals were created: Dialektikê to publish scientific articles, and Archivio di tipologia analitica, dedicated to the dissemination of raw data.

\subsection{Dialektikê: the voice of the Groupe international de recherches typologiques}

From 1969 to 1989 Laplace organised annual typology seminars in Arudy (a village in the French Pyrenees). In 1972, he published the first issue of the Cahiers de typologie analytique, a journal intended to collate the studies and communications presented during the seminar ${ }^{45}$. From its second issue, in 1973, it was renamed Dialektikê. Cahiers de typologie analytique. Twelve issues were published from 1972 to 1987 , totalling 633 pages. The print run of Dialektikê has not been recovered, except for the third issue published in 1975: in a letter, Laplace mentioned that 90 copies had been printed ${ }^{46}$. Dialektikê was symbolically sponsored by the Institut universitaire de recherche scientifique of the Université de Pau et des Pays de $l^{\prime} A d o u r^{47}$. However, it was only funded by the subscriptions of the seminar participants. It is worthwhile to review this initiative in terms of division of labour. On the one hand, the typologie analytique researchers committed themselves to producing the journal. Scientists usually disregarded the material production of journal editing as they considered it outside the scope of science, and this task was frequently delegated to the printers. To the contrary, the typologie analytique group engaged their time and personal instruments, such as typewriters ${ }^{48}$, in ty-

\footnotetext{
${ }^{44}$ The crucial importance for a printing company to have special glyphs and qualified staff has been enlighten in a study on mathematical composition in the French Louis-Jean printing company in the $19^{\text {th }}$ and $20^{\text {th }}$ centuries (Laugier 2003).

${ }^{45} \mathrm{~A}$ digital version of this journal is available at https : //lithictypes . hypotheses . org/44.

${ }^{46}$ Letter from Georges Laplace to Sylvie Philibert, 03-02-1975, Georges Laplace's files at the Musée National de Préhistoire, Les Eyzies-de-Tayac, France.

${ }^{47}$ This university was officially created in 1972. For the academic year 1971-1972, Laplace was in charge of a course on Quaternary geology, in which he also included some lessons on prehistoric archaeology (as witnessed by the course typescript, private files of Christine Cabon, one of Laplace's collaborator.

${ }^{48} \mathrm{An}$ examination of the type fonts suggests that third typewriters were used: the first from 1972 to 1975 , the second from 1976 to 1986 , and the third only for the last issue of the journal in 1987 .
} 


\begin{tabular}{l|l|l|l} 
& $\mathrm{S}$ & $\mathrm{A}$ & \\
\hline $\mathrm{e}$ & 132 & 93 & 225 \\
$\bar{e}$ & 138 & 177 & 315 \\
\hline & 270 & 270 & 540
\end{tabular}

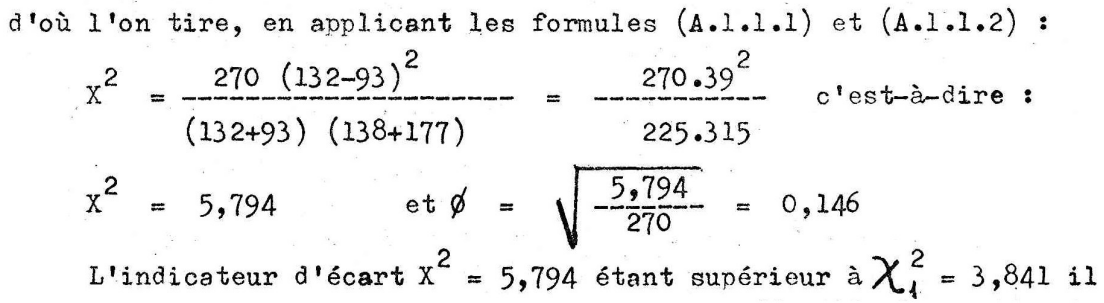

Figure 8: Self-production of the Dialektikê journal: example of mathematical composition mixing typing and hand-writing (from Laplace and Livache 1975, p. 11).

pographic compositions, notably facing the issues raised by the composition of mathematical formulas (Figure 8). On the other hand, this editorial work, including text copy-editing, registration of the subscriptions, shipment, and engaging in the network of journal exchanges with other institutions, was mostly done by Delia Laplace-Brusadin (1924-1997), Laplace's wife ${ }^{49}$. Being formerly an Italian archaeologist, a specialist in etruscology, she cut-back on her research after she joined her husband in France, as many women have done throughout the long history of science ${ }^{50}$. Dialektikê was printed by spirit duplication at Pau University, so re-typing the text on a special paper was required. Brusadin's crucial role in this task as witnessed by the occasional typing error, typical of an Italian native speaker writing in French (e.g. in the 1978 issue, "Typologie dell'industrie" instead of "Typologie de l'industrie").

In the second issue of Dialektikê in 1972, a note announced the creation of a new journal on typologie analytique:

Finally, we would like to announce the publication of Archivio di tipologia analitica on the initiative and in care of our friend Paolo Gambassini. This periodical is open to all those who may encounter typographical or other difficulties in making known the full data of their typological analyses. ${ }^{51}$

In this note, typographical issues are stated as the first difficulty encountered by typographie analytique practitioners wanting to publish their data to ensure data

\footnotetext{
${ }^{49}$ As witnessed by Christine Cabon, interviewed on the 11-05-2013.

${ }^{50}$ Brusadin's position is similar to the place held by women among historians of the Annales school some decades earlier, who were mainly restricted to tasks such as copy-editing, producing indexes and bibliographies (Zemon Davis 1992). For a history of the gendered bias in typewriting, see also Gardey 1999. This division of labour is long-standing in science: e.g. in $18^{\text {th }}$ century astronomy in France, women were limited to computation tasks (Lamy 2009, pp. 260-267).

${ }^{51}$ Nous signalons enfin la parution de Archivio di tipologia analitica sur l'initiative et par les soins de notre ami Paolo Gambassini. Cette publication périodique est ouverte à tous ceux qui peuvent rencontrer des difficultés typographiques ou autres à faire connaître les données intégrales de leurs analyses typologiques. Editorial note from Dialektikê, vol. 2, 1973.
} 
accumulation and sharing. However, the "other" difficulties were much more restrictive. Two examples can be given: firstly, the limitation due to archaeological journals being edited by rival researchers (refusing papers based on the typologie analytique); and secondly, a more material issue: sufficient editorial space in books or journals to print these data.

Jacques-Élie Brochier gave examples of the first type of limitation when I asked him in 2012 to tell the story behind some of his publications. He published numerous papers with Michel Livache, being two of the most active members of the Arudy group (Livache participated in 19 seminars and Brochier in 6). Regarding one of their articles, Livache and Brochier 2003, Brochier explained that it was published in the Rivista di scienze preistoriche for three reasons: 1) it was first submitted to a famous French journal of prehistoric archaeology and refused without any reasoned criticism (he received two very short evaluations) but only, according to him, by ideological opposition against the typologie analytique; 2) to the contrary, "in Italy you are not considered as a terrorist if you wrote something related to the typologie analytique" ${ }^{52}$; and 3) moreover, the Rivista accepted papers in various languages (e.g. Italian, French, English, German). About another paper, concerning the dating of the Chinchon prehistoric sequence, he said:

[...] I sent it to the Gallia journal, being sure it would be refused. Once again, for the same reasons: because it is grounded on the typologie analytique, and because it is a conception of the Upper Palaeolithic which current dominating group does not like. So, discussing the $t y$ pologie analytique in a French national journal nowadays is not possible. Every time I tried, I understood that it was not possible because it was refused. So, it is not without reason that Michel [Livache] and I have always published in Italy. At the Rivista they have no problem with it. Italy, Spain, everything is fine. ${ }^{53}$

Brochier sent his paper to Gallia in July 2012, a few months before our discussion. It was finally accepted and published two years later (Brochier 2016). This reflects how opposition against the typologie analytique has decreased over the years, mostly due to the generational renewal of researchers. After Laplace's death in 2004, the typologie analytique collective experience has been gradually integrated into the disciplinary history of archaeology, and remains actively taught and practised only in the Basque Country ${ }^{54}$

Considering the second type of limitation, namely the lack of space to print data, the Archivio di tipologia analitica, another Italian journal, was created to resolve this problem.

\footnotetext{
${ }^{52}$ Interview with Jacques-Élie Brochier, 07-12-2012.

53“"...] je l'ai envoyé à Gallia en étant sûr qu'il serait refusé. Toujours pour les mêmes raisons, parce qu'il y a de la typologie analytique derrière, et parce que c'est une conception du Paléo sup qui ne plaît pas au groupe dominant actuellement. Donc discuter de typologie analytique de nos jours dans une revue nationale française c'est pas possible. Enfin, à chaque fois que j'ai essayé j'ai compris que c'était pas possible parce que refus. Donc c'est pas pour rien qu'avec Michel on a toujours publié en Italie. À la Rivista, eux ça leur pose aucune problème. Italie, Espagne, tout va très bien.” Interview with Jacques-Élie Brochier, 04-12-2012.

${ }^{54}$ As observed in one of the latest publication on this method: Fernández Eraso and García Rojas 2013.
} 


\subsection{The Archivio di tipologia analitica: a controversial paper database}

The Archivio di tipologia analitica was a periodical initially created at the Istituto di Antropologia e Paleontologia umana of the Siena University in 1973; it was not published until 1998. This journal was first edited by Paolo Gambassini (19731977), then by Annamaria Ronchitelli (1978-1983), Fabio Martini (1984-1992), and finally by Mauro Calattini (1993-1998). It aimed to publish prehistoric archaeology data studied by the typologie analytique method. A note published in the first issue detailed:

[...] full publication of data not only takes up considerable space in journals but it also creates typographical problems and induces high printing costs. Consequently, the complete set of data used in an analysis remain completely unused, as prehistorians limit themselves to keeping them in their personal archives.

These considerations gave rise to the idea of publishing these "archives"; although in a traditional and economical way, they will serve to circulate data that would have otherwise remained with a limited number of specialists. ${ }^{55}$

The 91 articles published in the 21 volumes of the Archivio were -in most casesrelated to another paper previously published in a standard journal (mainly in the Rivista di scienze preistoriche (23\%) and in Rassegna di archeologia (9\%) ${ }^{56}$ ).

Each article in the Archivio is divided into two parts. The first part, the shortest, contains a list of general information about the data set. With some occasional variations, this list includes:

- the bibliographic reference of the related publication in which the data were summarised and analysed;

- the location of the archaeological site;

- the name of the researcher who conducted the sampling or excavation;

- the type of archaeological site (surface findings, stratigraphy, etc.);

- if relevant, the stratigraphic layer of the archaeological material;

- chronological information;

- the number of objects studied;

- the version of the typologie analytique taxonomy (occasionally more than one);

55“[...] infatti la pubblicazione completa dei dati, oltre ad occupare uno spazio notevole sui periodici, crea problemi tipografici ed elevati costi di stampa. In questo modo restano completamente inutilizzabili i dati integrali di un'analisi, che i singoli studiosi si limitano a conservare in un archivio personale. Da queste considerazioni è nata l'idea di pubblicare questo 'archivio' che, sia pur realizzato in veste artigianale ed economica, serva a far circolare quei dati che resterebbero altrimenti immobilizzati presso pochi studiosi." Archivio di tipologia analitica, vol. 1, 1973, p. 1.

${ }^{56}$ Rassegna di archeologia was a general archaeology journal created in 1979 in Piombino (Tuscany). 


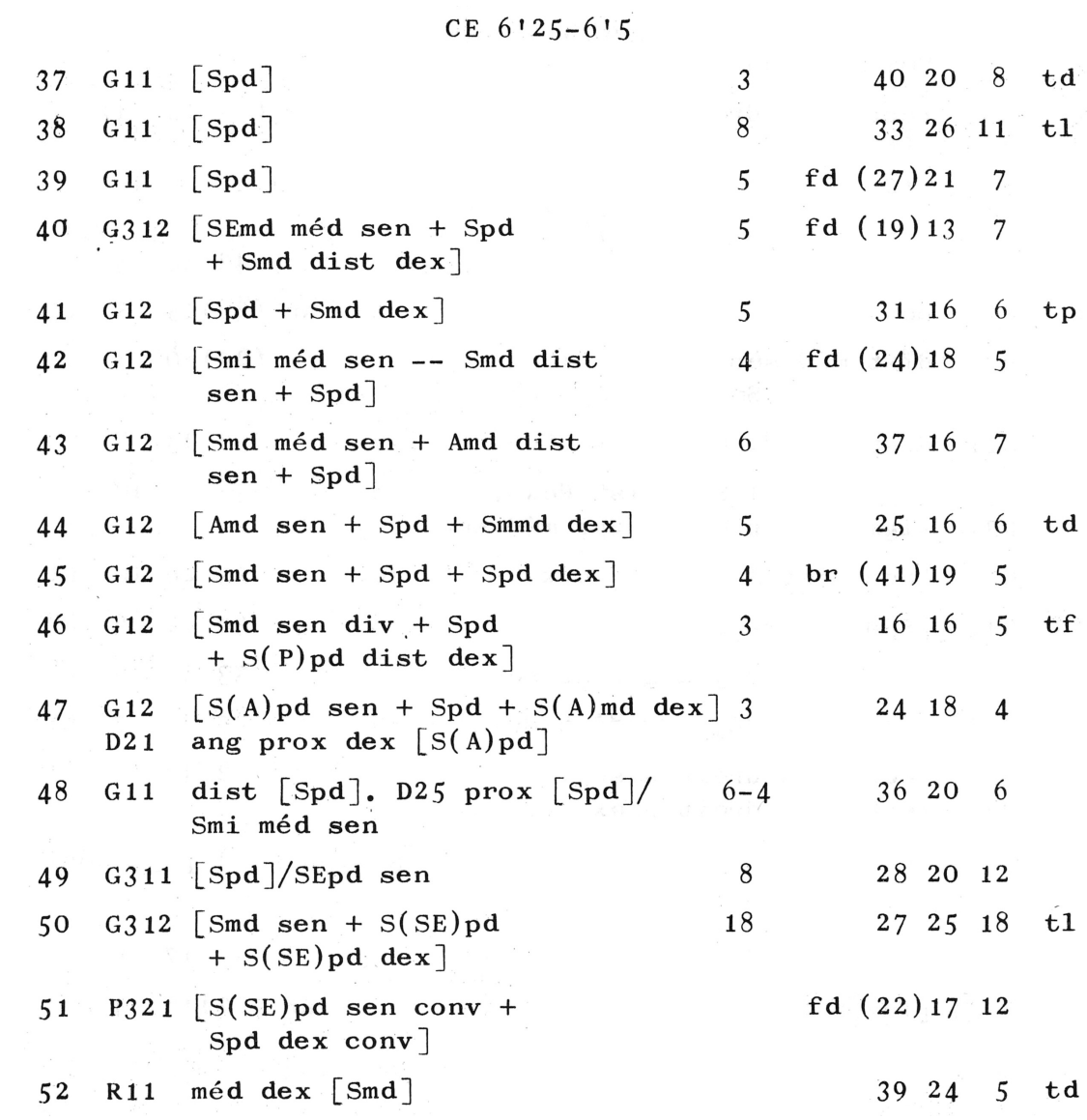

Figure 9: Excerpt from Fullola Pericot 1976, p. 15: for each object, the first column contains the object's identification number, the second column contains the analytical formula, and the last columns state its metric dimensions.

- the notation system used.

The second part of the article, the longest, includes a list of analytical formula, each related to one lithic object, presented with metrical measurements of its dimensions. An example of the page layout of the Archivio is shown in Figure 9: this page is an excerpt from a 127 page-long article by the Catalan archaeologist Josep Maria Fullola i Pericot (1953-), describing 3424 objects from the Cova del Parpalló site (these objects identified 3794 primary types, since a single piece can have multiple primary types). This article describes an unusual number of objects; "articles" in the Archivio were usually shorter than this example. However, independent of length, each article contributed to the editors' aim of accumulating data.

In this context, Figure 10 shows the yearly cumulative number of objects and primary types published in the Archivio between 1973 and 1998. The growth rate of this "paper database" is constant over this period; at the end a total of approximately 60,000 objects or primary types were described according to the typologie analytique method. The Archivio was first produce by the editors using a mimeograph, from 1973 to 1983 , after which they used a professional printing located 


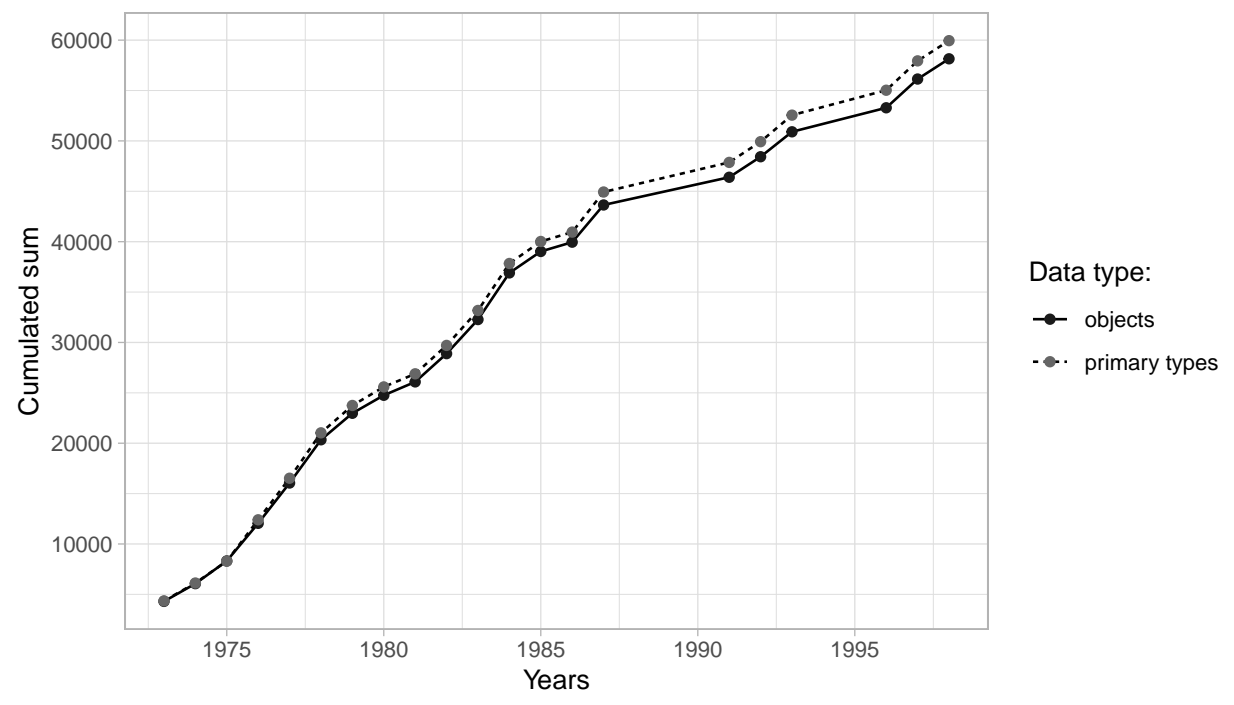

Figure 10: Yearly cumulative sum of the number of objects and "primary types" published in the Archivio di tipologia analitica. Data: Plutniak 2018b.

in Siena ${ }^{57}$. Despite this change, an introductory note in the 1984 issue informed readers that "the procedures for transcribing the analysis and introductory form remain unchanged" ${ }^{58}$, ensuring that data accumulation could continue.

One may think that data archiving is meaningless without a foreseen use of the archives. For archaeologists opposed to the typologie analytique it was out of the question to re-use their data. Some researchers of Laplace's generation considered the Archivio as "rubbish" ${ }^{59}$, and this opinion is still echoed by some archaeologists from the younger generation today: for example, one source told me that the Archivio is nothing more than "fire-starting paper" ${ }^{60}$. Concerning the typologie analytique practitioners, so far, I have only met a few researchers who re-used the data published in the Archivio.

Regardless of the actual use of these data, and keeping as a principle the need to archive them, the Archivio's contributors continued to maintain and to adapt this archive. In this respect, the use of computers from the end of the 1980s was a notable change regarding the material support of archaeological information, even if this change was made neither by Laplace nor by the Archivio's editors.

\subsection{Computer-based treatments of lithic analytical formulas}

In the second half of the $20^{\text {th }}$ century, standardisation, mechanisation, automation, and computerisation of typography were important steps in its technical development. All were mirrored in the development of the typologie analytique. Stan-

\footnotetext{
${ }^{57}$ The Archivio was first printed by the Tipolito Arteditoria Periccioli directed by C. Bruno, then by the Tipografia Senese.

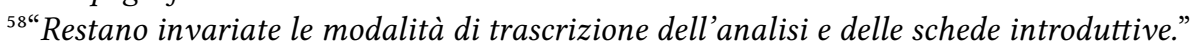

${ }^{59}$ Paolo Gambassini, during an interview, reported that a professor of prehistoric archaeology from the Sorbonne University (anonymised here) wrote him to stop receiving this "saloperie" (interviewed in French, 07-04-2014).

${ }^{60} \mathrm{~A}$ French prehistoric archaeologist, about 40 years old, interviewed on the 24-03-2014.
} 
dardisation through the typologie analytique method was not primarily intended for automatic processing; however, it gave de facto a precondition and led some practitioners, first, to elaborate on the relation between this method and computing ${ }^{61}$ and, second, to implement computer-based extensions of the methods.

The first attempts were conducted in Italy, by Mara Guerri and Anna Revedin, two collaborators of Paolo Graziosi. In 1983 and 1984, they worked with Alessandro Casavola from the computing service at the Florence University. The latter wrote a FORTRAN program to format and process data according to the typologie analytique standard which included four functions: data recording, checking and correction of records, information retrieval, and the computing of statistics included in the "structural analysis" which was a part of the typologie analytique. This work was then published in the Rivista di scienze preistoriche (Guerri and Revedin 1986). With regard to the Archivio, its computerisation started even later in 1991, from its $16^{\text {th }}$ issue, then directed by Fabio Martini. Subsequently, all the records were also stored on computer and diffused through $3 \frac{1}{2}$-inch floppy disk.

Many participants in the Arudy seminar came from Catalonia, besides Italy. Some of them contributed to the creation of the Departament d'Historia de les Societats Pre-Capitalistes $i$ d'Antropologia Social (History of pre-capitalist societies and social anthropology department) at the Autonomous University of Barcelona. There, Rafael Mora Torcal and his colleagues developed a software for the statistical analysis of archaeological data (Mora Torcal et al. 1990). Input formats included the analytical formulas according to the typologie analytique ${ }^{62}$.

Another computer implementation of the typologie analytique was elaborated by Michel Livache in France. In the 1980s, using a personal computer he bought himself (then, a significant financial expense), he wrote a BAsIC program able to read a list of analytical formulas, to parse them, and to summarise them with statistics. Livache considered that the typologie analytique -a method, he wrote, "that today we could call an expert-system" ${ }^{63}$ - and contemporary developments in computing had important similarities. Livache published a description of his program in the penultimate volume of the Archivio, in 1997. He stressed the need to disambiguate the lexicon and notation of analytical formulas. Indeed, their non-computerised definitions and uses give some syntactic and lexical flexibility. This is due to the free use of abbreviations of natural language terms (in this case, French):

We use a three-letter code per feature as often as possible, two letters are often insufficient and ambiguous. If, by this method, we want to count the feature "PD", the result will be the number of times the "PD" character string is encountered, either in PD, PDT, BPD or any other string containing the letters $\mathrm{PD}$. This is why it is important to be wary of the CONvex, CONcave, CONvergent $[\ldots]^{64}$

\footnotetext{
${ }^{61}$ See for instance this paper published in Dialektikê, Delfaud 1973.

${ }^{62}$ Interview with Rafael Mora Torcal, 10-03-2014.

${ }^{63}$ Livache Michel, De la typologie analytique, undated typescript, probably written in the 1980 , Georges Couartou files, Georges Laplace's nephew.

${ }^{64 " N o u s ~ u t i l i s o n s ~ l e ~ p l u s ~ s o u v e n t ~ p o s s i b l e ~ u n ~ c o d e ~ d e ~ t r o i s ~ l e t t r e s ~ p a r ~ c a r a c t e ̀ r e, ~ d e u x ~ l e t t r e s ~ s o n t ~}$ souvent insuffisantes et équivoques. Si par la méthode utilisée on veut décompter le caractère 'PD', le résultat sera le nombre de fois où la chaîne 'PD' est rencontrée, que ce soit dans $P D, P D T, B P D$ ou toute
} 


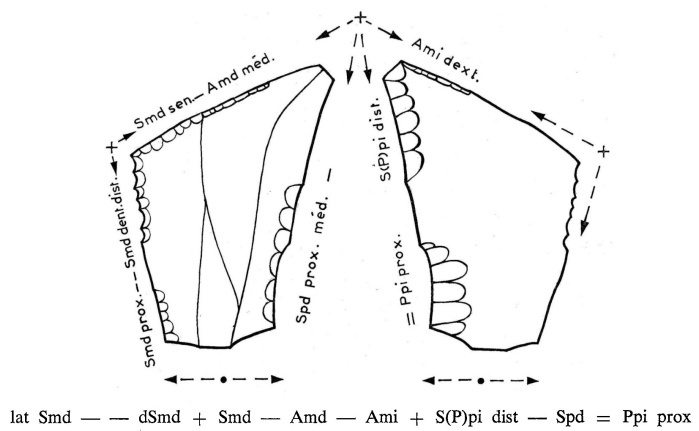

(a)

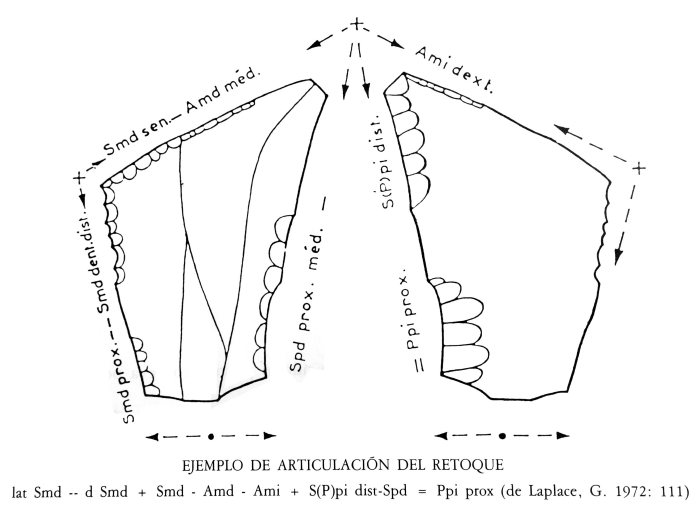

(b)

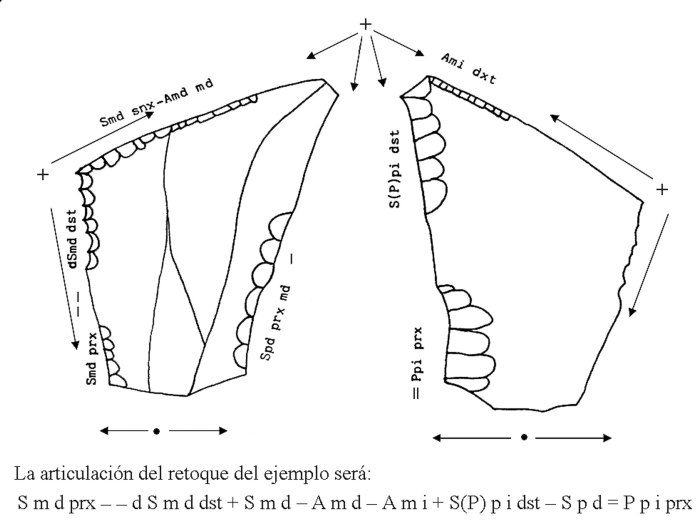

(c)

Figure 11: Linguistic variations in abbreviations: French original version (a, from Laplace 1974, p. 111), and two versions in Spanish (b, from Sáenz de Buruaga 1991, p. 43, and c, from Fernández Eraso and García Rojas 2013, p. 490).

In addition to intralinguistic variations, interlinguistic variations must be considered since the practitioners of the typologie analytique had different maternal languages: see, for example, the differences between a French and two Spanish versions of a retouch analysis on the same object (Figure 11). Practitioners of the typologie analytique have never carried out a computer-based standardisation of these interlinguistic variations of their vocabularies.

\section{Conclusion: towards Big Data. The persistent question of the materiality of representation systems}

From the case of the typologie analytique in prehistoric archaeology I investigated the effects of several publishing processes on the organisation of scientific activities and the content of scientific productions. Close examination of publication languages, controversies, the production history of journals, and the use of typography, identified relationships in which technical, material, and social dimensions are combined. These include mixing intellectual and typographical arguments, restricting conceptual innovation due to technical unavailability of printing re-

autre chaîne qui comprend les deux lettres PD. Voilà pourquoi il convient de se méfier des CONvexe, CONcave, CONvergent [...]" (Livache 1997, p. 133). 
sources, limiting the definition of a shared communication standard due to linguistic variation, and competition regarding the correct standard to elect.

However, as also shown in this paper, archaeologists have managed to control these effects, attempting to increase control of the publishing workflow and, at the same time, to enhance the systematicity and conceptual clarity of their methods of description and analysis. This attempt by the typologie analytique practitioners was, at the end, also related to the general evolution of several scientific editorial forms due to the diffusion of computers. In this context, it is noteworthy that computer-based methods for the typologie analytique occurred late. This suggests that its crucial aspect was not automation, but rather the collective definition of a rational means of communication. This situation can be compared with a contemporary and famous case from the field of computer science, the $\mathrm{T}_{\mathrm{E}} \mathrm{X}$ computer-based typesetting system. It was released in 1978 by the mathematician and computer scientist Donald Knuth (1938-) as a solution to what he judged as the low typographic quality of phototypesetting in mathematics. Besides being a modern typographical instrument, Knuth also considered $\mathrm{T}_{\mathrm{E}} \mathrm{X}$ as a communication means, a format which might significantly change the collective practice of mathematics. This is illustrated in his wish that "Perhaps some day a typesetting language will become standardized to the point where papers can be submitted to the American Mathematical Society from computer to computer via telephone lines., hoping that this language will be $\mathrm{T}_{\mathrm{E}} \mathrm{X}$ (Knuth 1979, p. 345).

In the aftermath of the typologie analytique, a higher degree of standardisation, which was previously one of the novelties and peculiarities of this method, became a common constraint for any archaeologist working with a computer. Moreover, the use of computer spreadsheets and database systems has increased de facto the level of standardisation and explicitness of data in scientific practice since the very functioning of computers requires it (and even if the user does not know or does not use this improvement). The publishing format developed in the typologie analytique framework conceptually anticipated formats that are becoming increasingly common in archaeology and science today. A first example relates to the generalisation of online publishing. Besides threatening offprints with extinction, online publishing has enabled the publication of large "supplementary materials" sections containing data, data descriptions, programming codes, etc. A second example concerns the use -although less developed- of online data storage services, and web semantic technologies such as ontologies and linked (open) data.

Nevertheless, this is not to say -far from it- that all the levels of rigour required by the typologie analytique practitioners have become common practice in archaeology today. The demand for data compatibility, accumulation, and sharing, and the use of a well-articulated and theoretically grounded set of statistical methods, is not widely adopted in the present-day prehistoric archaeology community. In this context, the issues raised by the typologie analytique practitioners in their time about the coding, archiving, and sharing of data remain of the greatest relevance today in archaeology and the humanities in general. 


\section{Acknowledgements}

I thank Paolo Gambassini, Jacques-Élie Brochier, and Rafael Mora Torca, who accepted to be interviewed, and Georges Couartou, Stéphanie Delaguette, Dominique Trousson, Christine Cabon and Maite García Rojas who shared some of the documents and information with me. I am also grateful to the people who helped me in the archive services I visited: Marie-Dominique Dehé $†$ (archives of the Musée national de Préhistoire), and Anais Rodríguez (Sociedad de Ciencias Aranzadi). Finally, I thank Christine Rabier, Laureline Meizel, Jean-Marc Pétillon and the two anonymous reviewers for their valuable comments on earlier versions of this article.

\section{References}

Adams, William Yewdale and Ernest Wilcox Adams [1991], A Dialectical Approach to Artifact Classification and Sorting. Archaeological Typology and Practical Reality, Cambridge: Cambridge University Press, $427 \mathrm{pp}$.

Adrian, Johns [1998], The Nature of the Book. Print and Knowledge in the Making, Chicago (Ill.): University of Chicago Press, $753 \mathrm{pp.}$

André, Jacques [2002], "Caractères, codage et normalisation. De Chappe à Unicode," Document numérique, 6, 3-4: Unicode, écriture du monde? Ed. by Jacques André and Henri Hudrisier, pp. 13-49, DoI: 10 .3166/dn . 6 .3-4.13-49.

Audouze, Françoise and André Leroi-Gourhan [1981], "France: a Continental Insularity," World Archaeology, 13, 2: Regional Traditions of Archaeological Research I, ed. by Bruce Trigger and Ian Glover, pp. 170-189, DoI: 10.1080/00438243.1981.9979824. Auroux, Sylvain [2000], "Les langues universelles," in Histoire des idées linguistiques. Tome 3. L’hégémonie du comparatisme, ed. by Sylvain Auroux, Bruxelles: Mardaga, pp. 377-396.

Bordes, François [1961], Typologie du Paléolithique ancien et moyen, 2 vols., Bordeaux: Imprimerie Delmas, 85-216 p.

Bordes, François [1965], “À propos de typologie," L'Anthropologie, 69, 3-4, pp. 369-377.

Boucard, Jenny and Norbert Verdier [2015], "Circulations mathématiques et congruences dans les périodiques de la première moitié du XIXe siècle," Philosophia Scientiæ, 19, 2, pp. 57-78, DoI: 10.4000/philosophiascientiae.1107.

Brézillon, Michel [1968], La dénomination des objets de pierre taillée. Matériaux pour un vocabulaire des préhistoriens de langue française, Paris: Éditions du CNRS, $416 \mathrm{pp}$.

Brézillon, Michel [1983], La dénomination des objets de pierre taillée. Matériaux pour un vocabulaire des préhistoriens de langue française, 3rd ed., Paris: Éditions du CNRS, 428 pp.; trans. 1968.

Brochier, Jacques-Élie [2016], "Les datations radiocarbone du Tardigravettien ancien à crans de l'abri de Chinchon 1 à Saumane-de-Vaucluse et la chronologie du Paléolithique supérieur récent provençal," Gallia Préhistoire, 56, pp. 8-27, DOI: 10.4000/galliap.290.

Broglio, Alberto and Georges Laplace [1966], "Études de typologie analytique des complexes leptolithiques de l'Europe centrale. I. Les complexes aurignacoïdes de la Basse-Autriche," Rivista di scienze preistoriche, 21, 1, pp. 61-121.

Coenen-Huther, Jacques [2003], "Le type idéal comme instrument de la recherche sociologique," Revue française de sociologie, 44, 3, pp. 531-547, DOI: $10.3917 /$ rfs. 443.0531. 
Delfaud, Jean [1973], "Quelques réflexions sur les rapports entre la Typologie analytique et l'Informatique," Dialektikê. Cahiers de typologie analytique, 1, pp. 8-12, DOI: 10.5281 /zenodo. 2583848 .

De Sonneville-Bordes, Denise and Jean Perrot [1954], "Lexique typologique du Paléolithique supérieur : Outillage lithique - I Grattoirs - II Outils solutréens," Bulletin de la Société préhistorique de France, 51, 7, pp. 327-335, DoI: 10.3406/bspf. 1954.3106.

Fernández Eraso, Javier and Maite García Rojas [2013], "Tipología analítica," in Métodos y Técnicas de análisis y estudio en arqueología prehistórica. De lo técnico a la reconstrucción de los grupos humanos, ed. by Marcos García Diez and Lydia Zapata Peña, Bilbao: Servicio Editorial de la Universidad del País Vasco, pp. 479-497.

Fullola Pericot, Josep Maria [1976], "Cova del Parpalló (Gandía, Valencia, Spagna)," Archivio di tipologia analitica, 4, pp. 13-140.

Gardey, Delphine [1999], "Mécaniser l'écriture et photographier la parole. Utopies, monde du bureau et histoire de genre et de techniques," Annales. Histoire, Sciences Sociales, 54, 3, pp. 587-614, DOI: 10.3406/ahess.1999.279766.

Gardey, Delphine [2008], Écrire, calculer, classer. Comment une révolution de papier a transformé les sociétés contemporaines (1800-1940), textes à l'appui, Paris: La Découverte, $319 \mathrm{pp}$.

Goody, Jack [1977], The Domestication of the Savage Mind, Themes in the social sciences, Cambridge: Cambridge University Press, $\mathrm{x}-179 \mathrm{p}$.

Guerri, Mara and Anna Revedin [1986], "Elaborazione statistica computerizzata delle industrie litiche preistoriche. Metodo analitico-strutturale G. Laplace 1972-1977," Rivista di scienze preistoriche, 40, 1-2, pp. 3-15.

Hempel, Carl Gustav [1965], Aspects of Scientific Explanation. And other Essays in the Philosophy of Science, New York: The Free Press, ix-505 p.

Hine, Christine [2006], "Databases as Scientific Instruments and their Role in the Ordering of Scientific Work," Social Studies of Science, 36, 2, pp. 269-298, DoI: $10.1177 / 0306312706054047$.

Hoyningen-Huene, Paul [2013], Systematicity. The Nature of Science, New York: Oxford University Press, xiii-287 p.

Hubert, Henry [1925], "Description d'objets néolithiques de l'Afrique Occidentale française," Bulletin du Comité d'Études historiques et scientifiques de l'Afrique Occidentale Française, 10, pp. 262-297.

Isaac, Manuel Gustavo [2013], "L'idéographie : une écriture de la pensée entre syntaxe et sémantique," Les dossiers de HEL, 9: Écriture(s) et représentations du langage et des langues, pp. 212-236.

Kantman, Sönmez [1969], "Essai sur la formation de concept du 'type' dans l'étude du Paléolithique," Quartär, 69, pp. 69-77, DOI: 10.7485/QU20_03.

Klejn, Leo S. [1982], Archaeological Typology, trans. by Penelope Dole, BAR International Series, 153, Oxford: Archaeopress, 382 pp.

Knuth, Donald E. [1979], "Mathematical Typography," Bulletin of the American Mathematical Society. (new series), 1, 2, pp. 337-372.

Krieger, Alex D. [1944], "The Typological Concept," American Antiquity, 9, 3, pp. 271-288, DOI: $10.2307 / 275785$.

Kristiansen, Kristian [2001], "Borders of Ignorance: Research Communities and Language," in Quo vadis Archaeologia? Whither European Archaeology in the 21st century? European Science Foundation Exploratory Workshop Mądralin, Oct. 12-13, 
2001, ed. by Zbigniew Kobyliński, Warsaw: Institute of Archaeology, Ethnology, Polish Academy of Sciences, and Foundation "Res Publica Multiethnica," pp. 38-44. Lamy, Jérôme [2009], "Noblesse et servitude du calcul astronomique. Les astronomes toulousains et la hiérarchie des mathématiques aux 18e et 19e siècles," Revue d'anthropologie des connaissances, 3, 2, pp. 253-272, DoI: 10.3917/rac.007.0253.

Lang, Valter [200o], "Archaeology and Language," Fennoscandia Archaeologica, 17, pp. 103-111.

Laplace-Jauretche, Georges [1957], "Typologie analytique. Application d'une nouvelle méthode d'étude des formes et des structures aux industries à lames et lamelles," Quaternaria, 4, pp. 133-164.

Laplace, Georges [1962], "Solutréen et foyers solutréens. Essai de typologie analytique sur le phénomène de solutréanisation," Munibe. Revista de la Sociedad de Ciencias Naturales Aranzadi, 14, 3-4, pp. 414-455.

Laplace, Georges [1964], Essai de typologie systématique, Annali dell'Università di Ferrara. Nuove serie, Sezione XV, Paleontologia Umana et Paleontologia, 1, Supplemento 2, Università degli Studi di Ferrara, 86 pp.

Laplace, Georges [1966a], "Le Magdalénien du Grand Abri Charasse à Entrechaux (Vaucluse)," in In memoriam do Abade Henri Breuil, Separata da Revista da Faculdade de Letras de Lisboa, Lisboa: Universidade de Lisboa, vol. 9, pp. 3-30.

Laplace, Georges [1966b], Recherches sur l'origine et l'évolution des complexes leptolithiques, forew. by Jean Bayet, Mélanges d'archéologie et d'histoire, 4, Paris: De Boccard, xii-586 p.

Laplace, Georges [1968], "Recherches de typologie analytique 1968," Origini. Preistoria e protostoria delle civiltà antiche, 2, pp. 7-64.

Laplace, Georges [1974], "La typologie analytique et structurale : base rationnelle d'étude des industries lithiques et osseuses," in Les banques de données archéologiques, Colloque national "Les banques de données archéologiques" Marseille, June 12-14, 1972, ed. by Mario Borillo and Jean-Claude Gardin, Colloques nationaux du Centre national de la recherche scientifique, 932, Paris: Éditions du CNRS, pp. 91-143.

Laplace, Georges and Michel Livache [1975], "Précisions sur la démarche de l'analyse structurale," Dialektikê. Cahiers de typologie analytique, 3, pp. 8-21, DOI: 10.5281/zenodo. 2583942 .

Laugier, Maurice [2003], "La composition des mathématiques. Évolution des techniques au travers d'une expérience professionnelle," Cahiers GUTenberg, 43, pp. 5-32, http://cahiers.gutenberg.eu.org/fitem?id=CG_2003_-_43_5_0.

Lenoir, Timothy (ed.) [1998], Inscribing Science. Scientific Texts and the Materiality of Communication, Stanford (Calif.): Stanford University Press, xv-457 p.

Livache, Michel [1997], "Exploitation d'une base de données de typologie analytique par un programme informatique simple. Codage et utilisation," Archivio di tipologia analitica, 20, pp. 133-136.

Livache, Michel and Jacques-Élie Brochier [2003], "L'évolution des industries pléni et tardiglaciaires en Provence et dans le bassin bas-rhodanien, lignées et convergences," Rivista di scienze preistoriche, 53, pp. 37-55.

Lowood, Henry E. and Robin E. Rider [1994], "Literary Technology and Typographic Culture: the Instrument of Print in Early Modern Science," Perspectives on Science, 2, 1, pp. 1-37.

McKenzie, Donald Francis [2004], Bibliography and the Sociology of Texts, Cambridge: Cambridge University Press, $128 \mathrm{pp}$. 
Mora Torcal, Rafael, Genís Roca i Verard, and Jorge Martínez Moreno [1990], "Estadística en arqueología. El programa GTS," Archivo español de arqueología, 63, 161-162, pp. 371-380.

Odell, George H. [2004], Lithic Analysis, Manuals in Archaeological Method, Theory and Technique, New York: Springer Science \& Business Media, 262 pp., DoI: 10.1007/978-1-4419-9009-9.

Olivier, Laurent and Anick Coudart [1995], "French Tradition and the Central Place of History in the Human Sciences: Preamble to a Dialogue between Robinson Crusoe and his Man Friday," in Theory in Archaeology. A World Perspective, ed. by Peter J. Ucko, London: Routledge, pp. 357-375.

Plutniak, Sébastien [2017a], Georges Laplace's archaeological offprints collection, Zenodo, DOI: 10.5281 /zenodo. 1235446.

Plutniak, Sébastien [2017b], "L'innovation méthodologique, entre bifurcation personnelle et formation des disciplines : les entrées en archéologie de Georges Laplace et de Jean-Claude Gardin," Revue d'histoire des sciences humaines, 31: Faire science, ed. by Camila Orozco Espinel and Yann Renisio, pp. 113-139, DoI: 10.4000/rhsh.435, HDL: 10670/1.rw3o20.

Plutniak, Sébastien [2017c], "The Professionalisation of Science - Claim and Refusal: Discipline Building and Ideals of Scientific Autonomy in the Growth of Prehistoric Archaeology. The Case of Georges Laplace's Group of Typologie Analytique, 1950s-1990s,' Organon, 49: Approche historique des structures de l'archéologie préhistorique et protohistorique aux XIXe-XXe siècles, ed. by Arnaud Hurel, pp. 105-154, HDL: 10670/1. y5rnm6.

Plutniak, Sébastien [2018a], "A Co-authorship Network Analysis of National and International Growth in Prehistoric Archaeology, Italy (1875-2000). Combining Bibliometric and Qualitative Data in History of Science Research," Mélanges de l'École française de Rome - Italie et Méditerranée modernes et contemporaines, 130, 2, pp. 417-430, DoI: 10.4000/mefrim.4052, HDL: 10670/1.1jzxoo, https://journals.openedition.org/mefrim/4052.

Plutniak, Sébastien [2018b], Summary of the prehistoric lithic industry data from the "Archivio di tipologia analitica" journal, Zenodo, Dor: 10.5281/zenodo.1235526.

Plutniak, Sébastien [2019], "Quinze ans de théorie et de méthodologie archéologique francophone : un retour sur les rapports entre science, politique, et édition, à l'occasion de la diffusion numérique de la revue Dialektikê. Cahiers de typologie analytique (1972-1987)," Les Nouvelles de l'archéologie, 155, pp. 36-41, DOI: 10.4000/nda.5861, HDL: 10670/1. aewuj5.

Plutniak, Sébastien and Massimo Tarantini [2016], “An Influential Outsider. Georges Laplace between French Institutions and Italian Prehistory," in History of Archaeology: International Perspectives, XVII Uispp World Congress. Volume 11 / Sessions A8b, A4a and A8a organised by the History of Archaeology Scientific Commission Burgos, España, Sept. 1-7, 2014, ed. by Géraldine Delley, Margarita Díaz-Andreu, François Djindjian, Víctor M. Fernández, Alessandro Guidi, and Marc-Antoine Kaeser, Oxford: Archaeopress, pp. 79-89, HDL: 10670/1.98h268.

Rider, Robin E. [1998], "Shaping Information: Mathematics, Computing, and Typography," in Inscribing Science. Scientific Texts and the Materiality of Communication, ed. by Timothy Lenoir, Stanford (Calif.): Stanford University Press, pp. 39-54.

Sáenz de Buruaga, Andoni [1991], El paleolítico superior de la Cueva de Gatzarria (Zuberoa, País Vasco), Anejos de Veleia, Series maior, 6, Leioa: Instituto de Ciencias de la Antigüedad, Servicio Editorial, Universidad del País Vasco, 426 pp. 
Shapin, Steven and Simon Schaffer [1985], Leviathan and the Air-Pump. Hobbes, Boyle, and the Experimental Life, Princeton (N.J.): Princeton University Press.

Soulier, Philippe [2007], "Un siècle de Bulletin de la Société préhistorique française (1904-2004) : déambulation bibliographique au cœur d'une société, savante et centenaire," in Un siècle de construction du discours scientifique en préhistoire. XXVI ${ }^{e}$ congrès préhistorique de France, Congrès du centenaire de la Société préhistorique française, Avignon, Sept. 21-25, 2004, ed. by Jacques Évin, Paris: Société préhistorique française, pp. 27-125.

Tarantini, Massimo [2005], "Georges Laplace in Italia tra tipologismo e antropologismo. Appunti per una riflessione storica," Rivista di scienze preistoriche, Supplemento 1, 55: Askategi. Miscellanea in memoria di Georges Laplace, ed. by Fabio Martini, pp. 31-40, DOI: $10.1400 / 206777$.

Tixier, Jacques [1963], Typologie de l'Épipaléolithique du Maghreb, Mémoires du Centre de Recherches anthropologiques, préhistoriques et ethnographiques d'Alger, 2, Paris: Arts et métiers graphiques, $209 \mathrm{pp}$.

Tomášková, Silvia [2005], "What is a Burin? Typology, Technology, and Interregional Comparison," Journal of Archaeological Method and Theory, 12, 2, pp. 79-115, DOI: $10.1007 / \mathrm{s} 10816-005-5666-4$.

Verdier, Norbert [2011], Le libraire-imprimeur ès mathématiques Mallet-Bachelier (1811-1864), http://images .math.cnrs.fr/Le-libraire-imprimeur-es.html.

Whallon, Robert and James A. Brown (eds.) [1982], Essays on Archaeological Typology, Kampsville seminars in archeology, 1, Evanston (Ill.): Center for American Archeology Press, xix-20o p.

Zemon Davis, Natalie [1992], "Women and the World of the Annales," History Workshop, 33, 1, pp. 121-137, https://www. jstor.org/stable/4289142. 